\title{
Analyzing The Farewell Sermon of the Prophet Muhammad (pbuh): A Critical Perspective
}

\author{
Muhammad Akram khan ${ }^{1}$ (D), Ali Furqan Syed ${ }^{2}$ (D) $\triangle$, Muhammad Junaid ${ }^{3} 8$ (D), Sajid mehmood shakir \\ 8 (iD) and Shahnawaz Shahid ${ }^{5}$ (iD) \\ ${ }^{134}$ MPhil Scholar, The Department of English Language and Literature, The University of Lahore, Sargodha Campus, Pakistan \\ ${ }^{2}$ Lecturer, Department of English Language and Literature, The University of Lahore, Sargodha Campus, Pakistan \\ ${ }^{5}$ Principal, Unique Group of Institutions, Lahore, Pakistan
}

$\square$ Corresponding Author: Ali Furqan Syed, E-mail: ali_syed786@yahoo.com

\section{ARTICLE INFORMATION \\ Received: July 15, 2021 \\ Accepted: August 20, 2021 \\ Volume: 1 \\ Issue: 1 \\ DOI: $10.32996 /$ ijls.2021.1.1.6}

\section{KEYWORDS}

Last Sermon, CDA, social discrimination, inequity, racism, Islam

\section{ABSTRACT}

Critical Discourse Analysis considers language use to be a form of social practice, and it is frequently used in political discourse, including written, verbal and visual public speeches. The last sermon of the Holy Prophet Muhammad (PBUH) is presented in this article as a Critical Discourse Analysis (CDA) in the perspective of social discrimination, inequity and racism. The study explores how the sermon brings about the true picture of Islam. The Prophet Muhammad's view has been reflected through textual and stylistic discussion in the study. This study also focuses the ideology of Prophet Muhammad PBUH that is revealed through the linguistic choices in the sermon and how the relationship between Muslim and Non-Muslim in the broader socio-cultural and political sense is represented. To achieve the goals of the study Fairclaugh's 3D Model was opted. The Prophet (PBUH) teaches his followers how to live-in peace with others, connect with them, and communicate with them without jeopardizing their own identities or the Muslims' sense of self. The findings of the study are that the Prophet's Farewell Sermon is seen as a road map for humankind, ensuring happiness, well-being, and prosperity for all people regardless of race, color, language, or other factors. The Prophet's expert use of the available media at the time added to the sermon's effectiveness. Teaching His disciples how to communicate and disseminate the sermon's teachings throughout the world. Furthermore, the study found that the Prophet's tremendous rhetorical and linguistic eloquence in placing words, phrases, sentences, and other elements in their right contexts played a crucial part in expressing His intended meanings to His audience. The study has some limitations as researchers could not analyse each element at the textual level, although they had given a little detail in the quantitative analysis of the text. The researchers suggest that future researchers go for complete analysis at the textual level and explore other potential areas.

\section{Introduction}

Discourse is known as the speech patterns and inside the community usage of language and dialects. Parallel speech patterns of the different people who belong to diverse remote places are being studied. The practice of analyzing things by breaking them down is known as analysis breaking down into parts. CDA is referred to as linguistic analysis of related writing and speech. The Key subject of discourse analysis is language used in specific social contexts. A Critical Discourse is presented in this article. The Fairclough 3D Model was used to analyses the iconic Holy Sermon of The Prophet Muhammad PBUH. Discourses are used to uncover overt or, more typically, hidden imbalances in social interactions. When speaking, the usage of words is important. Writing is regarded "social practice" that "infers a link between a specific discursive event and a specific discursive event," as well as the situation (as, institutions, and social structures) in which it occurs (Fairclough and Wodak, 1997).

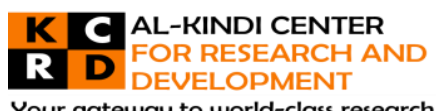

Your gateway to world-class research

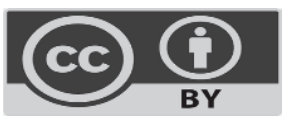

Published by Al-Kindi Center for Research and Development. Copyright (c) the author(s). This open access article is distributed under a Creative Commons Attribution (CC-BY) 4.0 license 
Arabs in the pre-Islamic period practiced and experienced all types of racial discrimination against each other, particularly against women. They used to oppress each other or even kill each other as a result of racial discrimination. What is more astonishing is that they used to bury female infants alive for their being just females. In addition, they used to enslave the black ones and buy and sell them as commodities. Ja'far bin Abi Taleb, addressed Al-Najashi, the King of Abyssinia at that time, highlighting the state of Arabs before Islam saying: We were overcome by a sea of ignorance and viciousness and adored idols, was in chastity, ate dead, and spoke outrages. We disregarded every feeling of humanity and the responsibilities of hospitality and neighborhood were also neglected; we identified no law but only the law of the strong (Al-Makhtum, 2013). After that, the Prophet Mohammed (PBUH) has been sent to eliminate all these traditions, practices, and concepts of racism through His noble teachings and remarkable discourses.

He (PBUH) addresses around 124,000 or 144,000 people, men and women of different nationalities and origins coming from different parts of the Arabic Peninsula. In fact, this sermon is not meant to address a specific group of people but mankind. Therefore, the study is devoted to highlighting the true concepts of anti-racial discrimination in the Prophet's Farewell Sermon to refute the false accusations attributed to Islam and Muslims and offer the solution for world racial discriminatory problems. Further to show how, even before to 1437, the Prophet (PBUH) established important human rights ideas, including women's rights. The CDA's applicable topics and domains involved in the Farewell Sermon. Rhetorical and linguistic aspects contribute to the power of the Farewell Sermon.

\subsection{Questions of the Study}

1. How do the Prophet Muhammad's views "in the last Sermon" reflect through the use of stylistic as well as textual strategies?

2. To what extent the linguistic choices and the ideology of Prophet Muhammad PBUH are reflected in the sermon?

3. How the relationship between Muslim and Non-Muslim in the broader socio-cultural and political sense is represented in the sermon through stylistic features?

These are researchable issues because the focus is on analyzing the language utilized in their speech. In order to discover the motifs, the researcher looked at the speaker's linguistic choices. Language is seen as the most important weapon for exerting power and expressing retribution against the dominant groups' influence in society. This research examines how the Prophet Muhammad PBUH used language to raise awareness of discrimination, racism, and unfairness and how He PBUH attempted to instill his ideology and themes in the minds of socio-politically oppressed people, particularly women. The researchers examined how the Holy Prophet PBUH used stylistic tropes such as metaphors to portray prejudice, racism, and injustice. At a broader socioeconomic level, the power relationship between Arabs and non-Arabs is examined. By evaluating the Holy Sermon through CDA, we can gain a political and historical perspective on how Arabs exercise power over non-Arabs.

\section{Background: Literature Review}

In this paper, references related to the main topic have been added along with the many variables contained in the study questions. Scholars have sought to weave a solid hypothetical framework into the parts in order to clarify further opinions. Various theorists' work has been significantly developed in the wide, interdisciplinary domain of CDA. CDA, according to Van Dijk (1998a) its main concern is to analyse any discourse in the form written or spoken by using various discursive practices as perspective in a society such as hegemony, dominance, disparity and discrimination and investigate how these activities are conducted in connection to socioeconomic and political considerations. From a political perspective.

CDA, according to Fairclough (1992) is a sort of discourse analysis that finds unusual relationships between various racial and ethnic groups. It focuses on text and chronological actions demonstrating uneven and ideologically influenced power relations. He examines how power is exercised in modern society through the elite's hegemonic attitude and ideological language. In discourse analysis, he distinguishes three levels. In the first stage, the CDA examines personal data. We can evaluate the speaker's experience and knowledge by considering his beliefs. Second, what impact do social interactions have on discourse, and third, what does the speaker realize about reality and identity? He believes that lexical and grammatical patterns in a dialogue reveal a speaker's social origin and identity. He contends that language shapes discourse and that power is exercised as a result of opposing sociopolitical ideas relations. Fairclough thinks that people from different social groups have different interpersonal and communicative values, which they communicate through their languages and speech. Political and ideological processes are in motion. Language is used for more than only describing objects, according to Brown and Yule (1985)

In addition to doing things, CDA investigates how people use language in everyday settings and how language reveals their cultural identities in a variety of social and ethnic backgrounds. They believe that the lexical and syntactic elements used in a language reflect the speakers' various socio-cultural backgrounds. Language, according to Halliday (1978) is a social act since it 
allows people to communicate with one another. Society as well as Language are intricately linked when it comes to dependency. Communication. Language shapes and constructs our identities (text).

Fairclough (1995) defines "linguistic study of discourse practice in a socio-cultural context." as inter textual analysis. This linguistic study assesses the text's lexical, syntactic, grammatical, and vocabulary levels. The cohesiveness, coherence, and layout of the text are examined. This study focuses on the text while accounting for all conversational behaviours. Fairclough (1995) defines intertextuality as a trait of any text in which bits of other texts are carried within the texts that are embedded in the text. The passage that was taken from another source has been thoroughly merged into the original. Suppose it rejects or accepts the original text's concept. Two sorts of intertextuality have been distinguish by him: Both the phrases interchangeably manifest inter-textuality and constitutive intertextuality. When quotations are used in the text, the first type is employed to substantiate and support the claim. Inverted commas are used to separate quotes in any text. A speech or a paper Visible intertextuality is the name given to this type of intertextuality.

The other is linked to frameworks for discourse that lead to the creation of new texts. This type of content, according to Fairclough, can be analysed using linguistic analysis. To describe his method of text analysis, (Fairclough N. , Language and Power, 1989) invented the phrase "critical language research." His most pressing concern The purpose was to bring attention to discrimination in social interactions and discursive practices that trample on people's rights. With the use of sociocultural lingo, he argues that language is used to obtain and maintain power. Hegemony. The text, which is the clothing of people's ideas, is how they exert their power. Language is employed to establish hegemony, authority, and control, according to Wodak (1997).

In order to comprehend the text's meanings, it is necessary to take a historical perspective on discourse. Every work has historical perspectives and conditions that aid in the clarification of meanings within that context, according to Gee (1990) and (Sampson, 1980). CDA analyses discourses systematically using a variety of approaches while taking into account socio-political and economic issues. Social semiotics is important in the interpretation of conversation since it is based on social factors in that specific situation.

The researcher discusses, explains, and analyses earlier books, papers, theses, and other works that have studied, explained, and analyzed the Prophet's Farewell Sermon, as well as other notable sermons and speeches, from various perspectives. For example, (Al-Makhtum, 2013) and (Al-Siba'ee, 1985) explained how the Prophet (PBUH) gradually transformed the Arabs' entire lives from discriminatory acts of all kinds to participation in a unified society enlivened by justice, equality, freedom, security, and peace over the course of 23 years. They also stated that the Prophet (PBUH) concluded His mission with the Farewell Sermon, in which $\mathrm{He}(\mathrm{PBUH})$ eradicated all forms of discrimination and completed the whole picture of Islam. (Al-Sallabi, 2009) discussed the Prophet's Farewell Lecture, giving readers with a study of the sermon in which he derives useful teachings and lessons from which people of all races, colours, and languages might live safely and happily. The Prophet's impressive discourse was described by (Al-Jahiz A. , 1998). He also mentioned the most important Arabic sermons, including the Prophet's Farewell Sermon, which is the best of them all (Zohery, 2010) employed textual analysis to understand and describe the Farewell Sermon's contents, structures, and functions. He established that the Prophet's Farewell Sermon encompassed many different areas of life through his textual analysis of the Prophet's Farewell Sermon (general and specific). He also stated that the Prophet's lecture established the principles of morality, chastity, modesty, justice, equality, brotherhood, and accountability. Furthermore, the Prophet (PBUH) eradicated economic exploitation, human servitude, paganism, transgression, and all other systems that are incompatible with Allah's system. Finally, the Prophet (PBUH) requested that His audience spread the teachings of His lecture across the world.

Wang (2010) used CDA to analyze Barak Obama's presidential addresses, focusing on transitivity and modality, to gain a better understanding of how language is utilized to serve ideology and power to comprehend the political aim of these speeches better. Wang summarized the aspects of Barack Obama's speeches using Halliday's Systemic Functional Grammar as follows: To begin, Obama employed straightforward, easy-to-understand language to close the gap between himself and the audience. Second, according to transitivity research, transitivity was used in the majority of Obama's speeches to demonstrate to the public what the government has accomplished, what they are doing, and what they will do. The researcher discovered that sermon(speech) was easily comprehendible.

Omoloso (2014) adopted the Theory of Universal Pragmatics examines the Prophet's Farewell Sermon to see the extent to which the Prophet's teachings in the sermon were adequate. According to Omoloso's study, the Farewell Sermon matched 'validity claims, and it was thus deemed fit and relevant for addressing humanity concerns. The document consequently advised that the Nigerian government, its agencies, and Nigerians in general learn, assimilate, and apply the Farewell Sermon's teachings, norms, and principles, as they were extremely fit in fixing their problems if Nigeria and Nigerians wanted peace. M. Ahmed and (Ahmed, 2016) presented a study in which they attempted to connect the principles, lessons, theories, constitutional rules, and human 


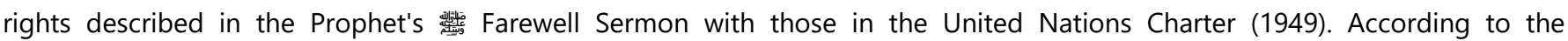
researchers, reports produced in a critical study enable the reader to perceive the similarities and influences of the Prophet Mohammed's statements on the United Nations Charter.

\section{Methodology}

Critical Discourse Analysis is used to examine the Holy Sermon of Prophet Muhammad PBUH (CDA). It looks at how verbal representation, syntactical organization, and comprehensible speech affect audience reasoning in a sociocultural setting with an ideology. The researcher's role is an examination of word-based/stylistic tactics as well as an interpretation of relational, expressive, and characteristic ideals in the sermon, with a distinct focus on wider sociopolitical and religious dimensions.

Study expands on earlier research by focusing and evaluating the Holy Sermon through linguistic choices, discursive practices, and socio-cultural and theological perspectives. It also examines how specific linguistic structures support the speaker in efficiently propagating his or her views and convincing others to receive them wholeheartedly. This project's theoretical framework is Critical Discourse Analysis (CDA), which the researcher chose. CDA critically examines discourses and reveals social activities such as discrimination, supremacy, abuse of human right, and ill-treatment of the people. It is an inter-disciplinary field in which social sciences and linguistics are brought together. Its debate subjects include ethnicity, the hegemonic attitude of the upper class toward the lower class, dominance, gender discrimination, discursive, ideolog. Only language is used as a criterion for analysis, and it demonstrates how speech displays discursive behaviors in a social setting. Researcher "in this article" exemplifies the issues with which CDA is most concerned. The topic includes elements such as social, cultural, political, and ideological inequality, all of which are fundamental topics that have been addressed. This theoretical framework gives a solid foundation and foundation for analyzing the variables described in the Holy Sermon. Ethical aspects are prudently considered while doing this research. There is no interaction with human subjects in this study because it is solely qualitative. There are no interviews in this study, hence there are no ethical concerns. Parts of the Prophet's Farewell Sermon have been distributed in many Hadith books, including Sahih al-Bukhari (2002), Sahih Muslim (2006), Sunan ibn Majah (2009), Sunan At-Tirmithi (1962), Sunan Al-Baihaqi (2003), Musnad Ahmed (2001), and others; however, the sermon has been collected by the historian Ibn Ishaq, as quoted Al-Jahiz in Al-Bayan wa Al-Tabyin (1998) gives the following text of the Farewell Sermon, which will be the study's studied text. When referencing a part of the sermon while analyzing it, the researcher refers to the original source, which is the book in which the quoted part is narrated. (Al-Jahiz, 1998)

For this investigation, the researcher used CDA as an approach. The research is completely qualitative in nature but quantitative data analysis methodology has also been used. Hence the current study uses mixed methodology. Fairclough's 3D Model has also been used. The following points summaries the methods used by the researcher to analyze the Prophet's 龆能 Farewell Sermon:

1. Because this is a descriptive, qualitative study employing the CDA technique, the researcher analyses the Holy Sermon using the CDA, with a focus on the denial of ideology of power, inequality, ideology, and discrimination.

2. The researcher looks at the English translation of the Arabic text of the Farewell Sermon rather than the Arabic original.

\section{Data Analysis}

The 'Farewell Sermon' has been hailed as one of the most important speeches in history, and it has had such an impact on people's minds. As a result, the researcher's goal is to bring it to light so that it can be properly analyzed and interpreted. The following sections will be used to analyses and interpret the data.

The quantitative approach has been used to get a better textual analysis of Prophet Muhammad PBUH's farewell sermon Figures 1, Fig2, Fig3, respectively, show the frequency of the repeated words and phrases besides the modal verb and anaphoric references \& relationship used in the speech. It is believed that it would provide a solid foundation for future textual and discourse study. This corpus has 642 total words.

\section{Textual Analysis}

One of the key pillars and crucial to the Fairclough model analysis is text. Text analysis is inextricably tied to the study of language used by humans in real-life situations. This methodology was originally labelled "Critical Language Study" since the main goal was to enhance awareness of socially exploitative relationships with a particular focus on language. Text analysis examines vocabulary choices, cohesiveness, coherence, and other stylistic aspects with a focus on the orator's explicit theme and wider socio-political view. This leads to a more in-depth examination than only the syntactic level. This analysis can be divided into two sections. In the first section, the theme, rheme, given information, and new information are highlighted through analysis inside the clauses or sentences. The second portion looks at the link between sentences or clauses, focusing on the four thematic progression types. Theme, Rheme, Given, and New Information are used to create an Informative Structure. The speech's 
sentences become more organized as a result of this. They provide the speech cohesion and coherence. We follow the informational and thematic structure to make statements grammatically and thematically correct. The message and the speakers' emotion are amplified by this cohesion. This gives the speaker the ability to leave a lasting influence on the audience. It arranges the sentences in a logical order. The order in which the given and new information is presented also contributes to the effectiveness of the speech. They act as a link between the audience and the speakers. Furthermore, Mark and Unmark and Multiple Themes act as a magnet, drawing the entire debate together. Given and new information are used to establish coherence in speech. The audience only gets one idea from the speech because of the connected sentences that exhibit cohesiveness and coherence.

\section{Textuality}

As previously stated, textuality refers to the complicated set of characteristics that texts must possess in order to be considered texts. Cohesion is the primary standard of textuality. Cohesion is defined as: It provides the bond and the link between various parts of the text using lexical, grammatical and other types of relationships. It is also a network of lexical parts. It's a feature of the text's linguistic surface. According to Hatim and Mason (1997), a text is cohesive if the lexical parts are conjoined together in any way.

The surface components of both linguistics and grammar, that is, rely on each other to establish and sustain text continuity. References, substitutions, ellipsis, conjunctions, and lexical coherence are the five primary markers of cohesive relationships, according to Halliday and Hasan (1976). When all of these cohesive relationships are applied to the sermon, it is discovered that all of the sentences in the Farewell Sermon are coherently and cohesively related and connected to one another on the one hand, and to the text as a whole on the other, forming a very beautiful golden necklace around the neck of mankind's history.

The Farewell Sermon's phrases are well-organized, as if they were a very fascinating and appealing picture created by a very intelligent and skilled painter. Every sentence is well-connected to the one before it and the one after it, and all of the sentences are well-sewn together by a skilled sewer to produce a fantastic, gorgeous outfit that mankind can wear.

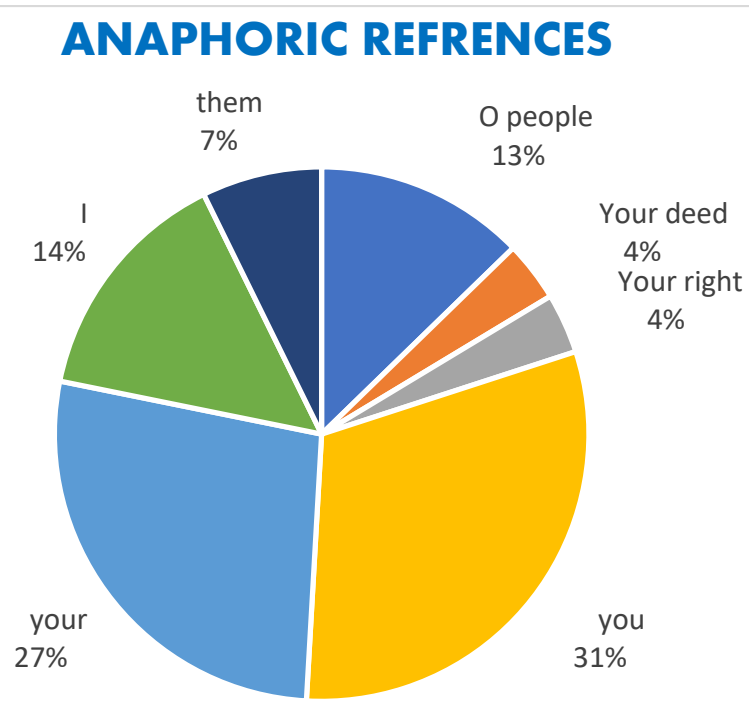

- O people " Your deed | Your right ॥ you - your - I - them

Anaphoric References, such as nouns, verbs, and so on, contribute to the sermon's overall cohesiveness. To demonstrate this, a close examination of the anaphoric relationships between the word's "O' People" and their referents "you" throughout the sermon reveals that all of the sermon's sentences are syntactically and semantically connected in a way that helps the audience or, later on, the readers to comprehend the sermon's meanings. There are numerous more anaphoric relationships between the words, such as "your women, your deed, your right" and their referents "them," the Prophet (PBUH) and His referent "I," and so on, all of which contribute significantly to the sermon's coherence and cohesion. 
Substitution, the second hallmark of cohesive connections, is also evident throughout the Prophet's speech. In the Prophet's words:

"And the first usury I begin with is that which is owed to..." (Al-Nisapuri, 2006)

The demonstrative pronoun "that" replaces the word "usury". Likewise, the Prophet (PBUH) says

"The first blood-revenge to begin, we'll look at what's due....", " (Al-Nisapuri, 2006)

. The demonstrative pronoun "that" replaces the word "blood-vengeance, Furthermore, in the Prophet's words. The marker of a cohesive relationship, substitution, helps in the sermon's cohesiveness.

Ellipsis, can also be observed in the Prophet's sermon statements. Holy Prophet PBUH, for example: Says

"O people, have I faithfully delivered unto you, my message?" "O Allah bear witness " (Al-Bukhari, Sahih Al-Bukhari , 2002) a powerful mumble assent" "O Allah! (Allahumma Na'm)

The magnificent use of ellipsis in the Prophet's companions' response is evidented when they respond "yes," which indicates "yes, you have conveyed the message." " contributes significantly to the sermon's cohesiveness.

There are four sorts of conjunctions in the fourth marker of cohesive links, extension, additive, adversative, and causalconditional conjunctions. According to the Prophet (PBUH),

"Truly, the hereditary distinctions that were pretensions to respect in the Era of Ignorance have been laid aside forever, except for the custodianship of the Ka'aba" (Al-Jahiz A. , 1998)

The Prophet (PBUH) skillfully and positively uses extension types of conjunctions such as " and" "except," to extend and connect sentences. In numerous phrases of the Prophet's discourse, the additive conjunction 'and' guarantees that the discourse's meaning remains consistent

The additive conjunction 'and' connects the sentences together in order to ensure the continuity of the meaning in the sermon and make the sentences cohesively connected

The sermon's lexical cohesion is also noticeable throughout; the sermon's words work together harmoniously in extremely amazing partnerships. The words "Arab" and "non-Arab" are interwoven harmoniously in the Prophet's words:

"Arab has no distinction above non-Arab other than God fearing" (Al-Jahiz, 1998)

According to Van Dijk, sentence coherence is "based not only on the sequential link between expressed and interpolated propositions, but also on the topic of discourse of a specific passage" (Dijk, 1997)As a result, a text is said to be cohesive if its pieces are harmoniously interwoven, and it is said to be coherent if its meaning is appropriate. That is why a text might be coherent but unintelligible at times.

At Lexical level The Prophet's Farewell Sermon contains declarative and imperative sentences if you look closely at the text. Declarative clauses thereby deliver heavenly messages that are intended to govern the lives of the audience and subsequent generations. For example, in the family, the prophet outlines the complementary rights and responsibilities of husbands and wives. He (PBUH) declares:

"O' people: verily you owe your women their rights, and they owe you yours"

Imperative clauses are also used to instruct or order people to carry out certain directives and responsibilities. As a result, the sermon contains multiple imperative phrases that must be followed by both the listeners and the broader public. For example, the Prophet (PBUH) declares, 
"let whoever has been given something for safekeeping give it back to him who gave him it" (Al-Jahiz A. , 1998)

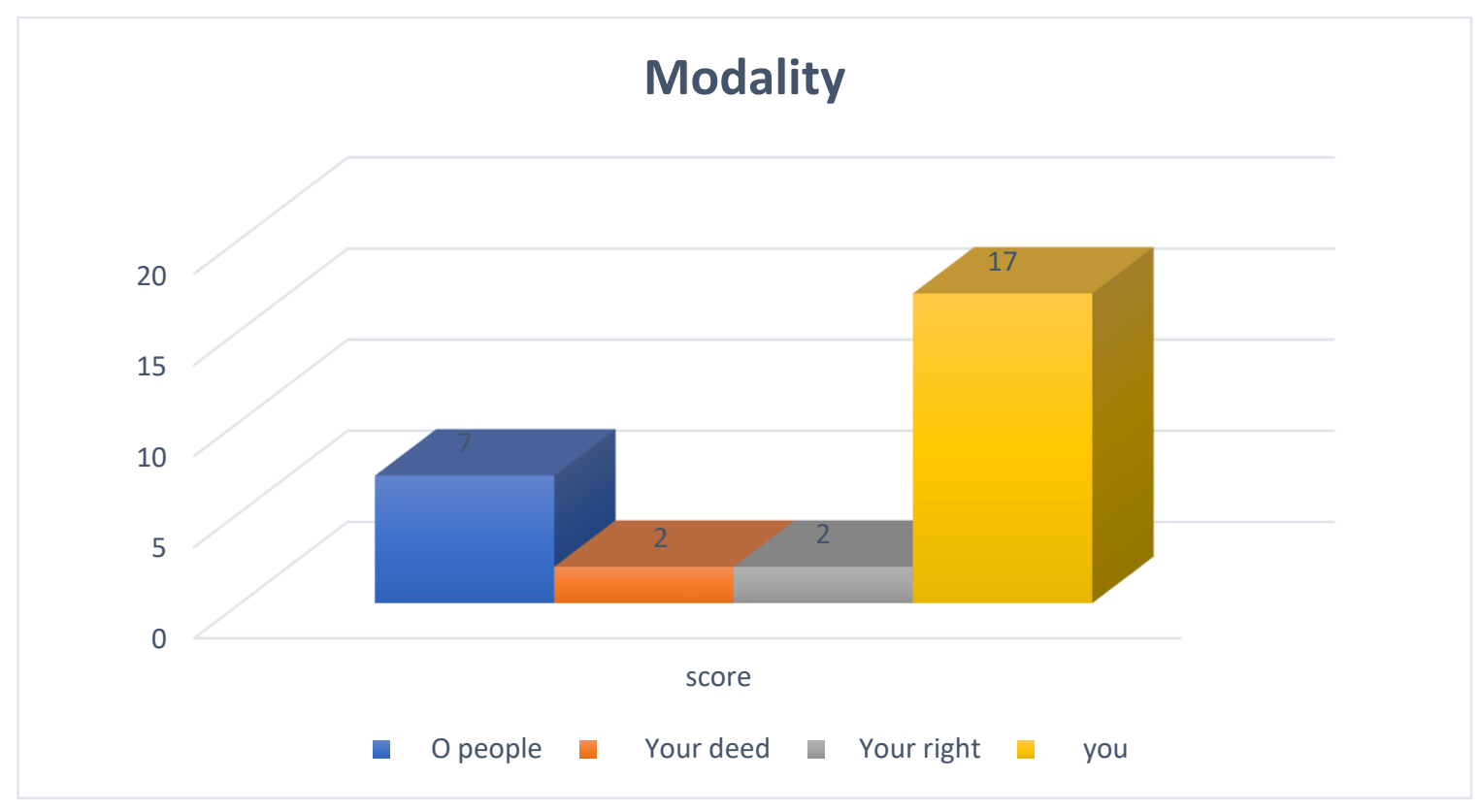

Fig.2

Modality simply refers to the use of modals to express thoughts, ideas, and attitudes. Some of the modal verbs in the Prophet's Farewell Sermon suggest that the Prophet's teachings, as conveyed in the sermon, signify possibility, certainty, obligation, and so on. For instance, in His first words, He says:

\section{"O' people lend me ..., I shall ever be amongst you again" (Al-Jahiz, 1998)}

He (PBUH) employs the modal verb "shall," which denotes certainty and predictability. Furthermore, the Prophet (PBH) employs the word "shall" here to avoid shocking His audience, who love Him even more than themselves, with such news, which could divert their focus away from the sermon's essential teachings. The modal verb "must" is used by him (PBUH), indicating predictability and certainty. Furthermore, the Prophet (PBH) uses the word "shall" to avoid shocking His audience, who love Him even more than they love themselves, with such news, which could divert their focus away from the sermon's essential teachings.

The sermon's logical sequencing of ideas is one of its strongest features. For example, the Prophet (PBUH) compares things that are very much respected and sacred to the people at that time (the Day of Arafah, the Month of Dhul-Hijja, the Town of Makkah), either before or after Islam, to things that are not respected or sacred to the people at that time (life and property), in order to change the non-respected to be very much respected, not only on the Day of Arafah, but also in the Month of Although this balance occurred at the same time, the use of the lovely simile demonstrates the logical progression of both the phrases and thoughts. O' people: until the day you meet your Lord, your lives and your possessions are as inviolable to each other as the inviolability of this day, the month, and the place you are now in," the Prophet (PBUH) says. Hadith No. 1739. (Al-Bukhari, Sahih Al-Bukhari. Beirut, 2002) Furthermore, the Prophet (PBUH) begins His the sermon with general universal themes (blood and property) that all humans share. Then $\mathrm{He}(\mathrm{PBUH})$ digs into the nitty-gritty of these prevalent difficulties.

\section{Pragmatics}

Pragmatics is concerned with communicative goals, particularly the study of language and interaction in context. It deals with the gist of how individuals make sense of language. The utterance's meaning extends beyond what is actually stated. Pragmatics is primarily concerned with "how we achieve meaning in specific circumstances, taking into account topics such as how, when, and where it is spoken, who says it, what the speaker-hearer relationship is, and how we make an intellect of perplexing uses of language" (Baker \& Ellece, 2011)

The Prophet's sermon was delivered on the 10th of Dhul-Hijjah, the Day of Arafah, in Makkah, in the Urana Valley. According to (Al-Siba'ee, 1985), the Prophet (PBUH) addresses over 114,000 individuals, but (Al-Makhtum, 2013) claims that the Prophet (PBUH) addresses roughly 124,000 or 144,000 people, men and women of various races, colours, and languages. Before Islam, a 
vast number of individuals were engaged in various forms of discrimination. However, following Islam, they became close brothers, accepting the Prophet's teachings and principles as outlined in the Farewell Sermon. They've also travelled all around the world, spreading the word.

The sermon's ideals and inviting people of all races, colors, and languages to follow the Prophet's Farewell Sermon. Also, the Prophet's (PBUH) relationship with His audience is very close, as evidenced by the intimate and seductive opening of the sermon, in which the Prophet (PBUH) has paved the path into the thoughts and hearts of the audience to listen to Him carefully. "O people, listen to me attentively, for I do not know whether I shall ever be among you again after this year," the sermon begins (Al-Jahiz, 1998). According to (Omoloso., 2014), the Prophet (PBUH) intends to "guarantee that His words can impact His audience such that they may take up an interpersonal relationship with Him" in the beginning (p. 80). Furthermore, the Prophet's repeated call "O' people" throughout the discourse demonstrates the Prophet's deep love for His audience and the people of the globe, as well as His determination to lead them down the correct road. Furthermore, the Prophet's (PBUH) intimate contact with His audience may be seen in His helpful advise, in which He (PBH) does not abandon them after His death. "I have left among you that which, if you take it, will never lead you astray from me: the Book of Allah," he (PBUH) states (Al-Nisapuri, 2006). Furthermore, His comment " anyone who is present should inform whoever is absent." demonstrates His deep love for His followers, particularlynd for mankind in general (Al-Bukhari, Sahih Al-Bukhari. Beirut, 2002). He (PBUH) does not want to deny people all around the world the opportunity to live under the protection of the sermon's excellent lessons.

Furthermore, the contents of the Prophet's speech are intended to be thoroughly comprehended because the sermon is delivered in Arabic, the audience's native tongue, with no unclear language usage. The audience's "yes" response to the Prophet's question, "Have I presented the message?" proves this. (Al-Bukhari, Sahih Al-Bukhari. Beirut, 2002). Following that, the text of the speech is translated into a variety of languages, one of which is English, as per the Prophet's wish to give His message to humanity. Furthermore, the sermon is extremely important because it touches on a variety of topics.

\section{Context}

The text's strength is demonstrated not simply through linguistic and rhetorical methods; rather, the context and its relationship to the text also contribute to the text's power. According to Van Dijk (2008), the text's context, which is intimately tied to it and in which it appears, plays a significant role in the text's strength. As a result, the Prophet's speech has had such an impact because it is so closely tied to its delivery setting.

One of the most essential teachings that the Prophet (PBUH) wishes to convey is that all individuals are born equal and that the only thing that separates them is their piety and good acts (the one who is the most God-feared). The Prophet's (PBUH) words are conveyed in a way that helps the audience understand the notion of equality and imprints the Prophet's (PBUH) words in their hearts, as well as in the hearts of humankind in general. (Richards and Schmdit, 2010) put it clearly when they remarked that listeners will understand best if they meet or live in an environment where the speaker addresses their needs or the conditions surrounding them. This is known as the 'situational context.' As a result, the meaning of utterances, etc., in the context of a scenario is defined not only by the literal meaning of the words employed, but also by the context or scenario in which they occur:

Despite the fact that many were not able to attend the Prophet's Farewell Sermon, he depicts the situation and atmosphere in which it is delivered. In reality, the Prophet (PBUH) carefully selects the time and location in which He delivers His sermon, which has made it more powerful, effective, and intelligible. He (PBUH) preaches in a sacred month, Dhul-Hijja, on a holy day, Arafat, and in a sacred city, Makkah, i.e. the time and day when a large number of men and women from all over the Arabic Peninsula meet.

As a result, the setting in which the sermon is presented plays a critical role in its interpretation. In other words, the setting in which the sermon was delivered aids in understanding the sermon and contributed to the sermon's efficacy in the audience's ears and hearts to a large extent. For example, the Prophet (PBUH) chose to deliver His discourse in a sacred month, on a sacred day, and in a sacred place in order to demonstrate the holiness of everyone's blood and property, regardless of race, color, or nationality. As a result, the situation fits the ideas that the Prophet (PBUH) intended to instill in the hearts of His audience, which is the sacredness of one's blood and property, to a large extent.

Seeing the affluent and the poor, white and black, strong and weak, Arabs and non-Arabs, and people of many nations, including the Prophet (PBUH) Himself, wearing the same garments, performing the same Hajj rituals, and saying the same phrases during the Hajj is indeed a lovely sight. In this context, this excellent image depicts the practical aspects of equality, emphasizing the 
concepts the Prophet (PBUH) wished to impart to His audience in His discourse. This incident also supports the sermon's point that no one is superior to another except through piety and good works.

To put it another way, the practical aspects of equality practiced by pilgrims from all over the world correspond to the meanings of the messages that the Prophet (PBUH) delivered to humanity, giving the Prophet's (PBUH) words more strength and making them more effective, intelligible, and significant. As a result, the Prophet's lecture, particularly the words:"All of you are from Adam, and Adam was from the ground. The noblest of you in Allah's sight is the most god fearing: Arab has no merit over non-Arab other than god fearing" (Al-Jahiz, 1998) is inextricably linked to the context in which they are delivered, and this, in turn, enhances the Prophet's Farewell Sermon's force and effectiveness. Furthermore, wearing the same attire allows the audience to concentrate better on the Prophet's lecture because their attention is not diverted by admiring each other's colorful clothing.

The Prophet (PBUH) narrated by says, "O' people: your lives and your property, until the very day you meet your Lord, are as inviolable to each other as the inviolability of this day you are now in, the month you are now in, and the town you are now in" (Al-Bukhari, Sahih Al-Bukhari , 2002)

"It is true, O People, that you have certain rights in relation to your women...,"

As Rasulullah s.a.w. taught us, women and men are partners. As partners, women and men complement each other. Because we are partners, we share a lot of things as husband and wife. To create a harmonious living environment, it is necessary to understand and be kind to one another.

\section{"I enjoin you to treat women well and be kind to them."}

Rasulullah s.a.w. improved the status of women during his lifetime. Several patriarchal practises that existed before the arrival of Islam were altered. Women were given a voice and a space to air their grievances and express their opinions. They played an important role in the development of Islam.

Unlike other leaders, the Prophet (PBUH) is not surrounded by bodyguards when delivering a sermon, nor does He (PBUH) wear special clothing or have a special place to sit or walk in, and this simplicity and humility fully appropriates His messages about equality and makes His words more powerful and true. As a result, the context in which the Prophet (PBUH) delivers His sermon enhances the strength of His words and the comprehension and effectiveness of His messages. Such practical activities by the Prophet (PBUH) assist the audience in completely comprehending the true meaning of equality. Furthermore, the Prophet's (PBUH) practical behavior imprints the sermon's words in the minds and hearts of His followers, ensuring their immortality in the collective memory of mankind. As a result, "an eternal sentence" is defined as "a sentence whose interpretation is independent of its context" (Reboul, 1797)

As a result, the environment in which the Prophet's Farewell Sermon is delivered is crucial. This, in reality, aids the audience in completely comprehending the Prophet's words and ensures the sermon's longevity in the collective memory of mankind. The pragmatics of the sermon are also aided by the fact that the sermon is embedded in the setting in which it is delivered. Furthermore, the Prophet's words, concepts, and teachings gain strength and life as a result of the context, overcoming false claims that $\mathrm{He}(\mathrm{PBUH})$ and His followers are bigots, violent, and so on.

\section{Discussion}

\section{Discussion/ Recommendations}

Based on the CDA methodology, this study examines the Prophet's Farewell Sermon. The CDA methodology, which is primarily concerned with power relations in language, was used to explore the problem of anti-racial discrimination in the study. Islam and Muslims have been accused of being racists toward people of other faiths and the West. The researcher examined the Prophet's Farewell Sermon in order to rebut these false accusations and present the correct understandings of Islam and Muslims. As a result, the researcher delivers the study's most noteworthy findings in this chapter. The researcher will offer these findings in terms of or in the form of replies to the study's questions, as follows: What are the important issues that the Prophet (PBUH) addresses in his Farewell Sermon as a powerful leader to help the society of His audience, in particular, and all people all over the world, in general, eliminate the problem of racial discrimination and prove that Islam and Muslims are not racists, terrorists, violent, and so on? According to the CDA interpretation of the Prophet's Farewell Sermon, the Prophet (PBUH) and His honest followers are neither racists, violent, tyrannical, or have animatic attitudes toward members of other religions, as the Western people and media have claimed. This has been proven through an examination of the issues addressed by the Prophet (PBUH) in His sermon, the most important of which are the oneness of the universe's creator, the oneness of the 121 origins of the human 
race, the oneness of the criteria of human superiority that are accessible to any human being regardless of race, color, language, etc., and the oneness of humanity's enemy, Satan. Morality, chastity, modesty, fairness, equality, brotherhood, responsibility, economic exploitation, human enslavement, paganism, and transgression are all addressed by the Prophet (PBUH). By examining these difficulties, the study has concluded that the Prophet (PBUH) abolishes all forms of racial discrimination between Arabs and non-Arabs from that point on. According to the sermon, everyone is equal, and no one is greater than another except through devotion and good deeds, regardless of race, color, or language. That is why the Sermon stands out among other sermons in terms of universality.

Furthermore, the study revealed that in light of the sermon, the Prophet (PBUH) established the major universal principles of human rights, the most important of which are the right to life, the right to equality and justice, the right to property, the right of the poor upon the rich, the right to protect honor, and the rights of women, indicating the sermon's powerful issues.

To sum up, the study has determined that the Prophet (PBUH) is not only an anti-racist leader, but also a founder of security, peace, equality, justice, and freedom. To be honest, the Prophet's Farewell Sermon can be considered a Humanistic Approach for humanity to live by, especially for women who have discovered their rightful places in Islam's shadows, and this might be one of the researcher's future suggested researches. It should also be shown to the world that the ideology behind the "Women March" has no connection with Islam and its teaching. Here are few suggestions for changing this misconception about Islam and Muslims: We should share the Prophet's Farewell Sermon's noble teachings with the world and obey the Prophet (PBUH) when

He says, "Then let whomever is present tell whomever is absent" (Al-Bukhari, 2002)

1. Islamic scholars must always rebut false accusations and dispel Islam's misconceptions.

Not only that, but they should devote themselves to promoting Islam in a wise and equitable manner.

2. Conferences should be arranged monthly or annual to convey the correct picture of Islam and Muslims. The Prophet's utterances provide rich ground for scholarly research and research, allowing for various discourse studies and the development of new thoughts and important ideas. Islamic nations must financially and through the media sponsor and support such conferences.

3. Because media is such a strong instrument that impacts the majority of people, Muslims should use various forms of media to convey the noble teachings of Islam regarding the issue of discrimination in the society and Racism specially against women, such as films or producing books.

\section{Conclusion}

On the basis of the CDA method, this study examines the Prophet's Farewell Sermon. It has addressed the notions of anti-racial discrimination in the Prophet's Farewell Sermon using the CDA method, which is primarily concerned with power relations in the language. Islam and Muslims have been accused of racism toward the West and members of other faiths. These assertions were debated and disputed using the CDA method in light of the Prophet's Farewell Sermon. The study also discovered that the Prophet (PBUH) addresses universal concerns like inequality, racism, discrimination, and human rights, ending the discourse with immortality in human history. In dealing with such universal matters, the Prophet (PBUH) abolishes all forms of racial prejudice between Arabs and non-Arabs since then and establishes global laws, principles, and criteria available to people everywhere. Among other sermons, the sermon achieves universality. Furthermore, the study revealed that the Prophet (PBUH) is not only an anti-racist leader, but also a founder of human rights, the most important of which is the right to life, the right to equality and justice, the right to property, the right of the poor to the rich, the right to protect honor, and the rights of women, as outlined in the sermon. Moreover, Islam is a divine religion that embraces people from all walks of life, and it is a divine religion that provides a balanced view of both the secular and religious aspects of human existence through its notion of worship. Furthermore, the Prophet (PBUH) teaches his followers how to live-in peace with others, connect with them, and communicate with them without jeopardizing their own identities or the Muslims' sense of self. As a result, according to the findings of the study, the Prophet's (PBUH) Farewell Sermon is seen as a road map for humankind, ensuring happiness, well-being, and prosperity for all people regardless of race, color, language, or other factors. The Prophet's (PBUH) expert use of the available media at the time added to the sermon's effectiveness. Teaching His (PBUH) disciples how to communicate and disseminate the sermon's teachings throughout the world. Furthermore, the study found that the Prophet's tremendous rhetorical and linguistic eloquence in placing words, phrases, sentences, and other elements in their right contexts played a crucial part in expressing His (PBUH) intended meanings to His audience.The study has some limitations as researchers could not analyse each element at the textual level although they had given a little detail in the quantitative analysis of the text. The researchers suggest that future researchers should go for complete analysis at the textual level and explore other potential areas. 


\section{References}

[1] Ahmed, M. \&. (2016). The last sermon of the holy Prophet (PBUH) and the charter of the United Nations. Humanities, Arts, Medicine and Sciences.

[2] Al-Bukhari. (2002). Sahih Al-Bukhari . Lebanon:: Dar Ibn Kathir.

[3] Al-Bukhari. (2002). Sahih Al-Bukhari. Beirut. Beirut, Lebanon: Dar Ibn Kathir.

[4] Al-Jahiz. (1998). Al-bayan wa Al-tabyin. Qairo, Egypt: Al-Khanji Library.

[5] Al-Jahiz, A. (1998). Al-bayan wa Al-tabyin. Qairo, Egypt: : Al-Khanji Library.

[6] Al-Kahtany, A. (2000). The universality of Islam. UK: Al-Muntada Al-Islami. UK: : Al-Muntada Al-Islami.

[7] Al-Makhtum, A.-M. (2013). The Sealed nector. Cairo, Egypt: Dar Ibn Al-Jawzi.

[8] Al-Nisapuri, M. (2006). Sahih Muslim. Al-Ryad: Dhar Taibah. Al-Ryad: Dhar Taibah.

[9] Al-Sallabi, A. M. (2009). Al-Sirah Al-Nabawiyah. . Egypt: Al- Maktabah Al-Eslamiah for Publication and Distribution.

[10] Al-Sheha. (2000). Women in the shade of Islam. Riyadh: Islamic Educational Center.

[11] Al-Siba'ee, M. (1985). Al-Sirah Al-Nabawiyah Drusun wa 'ebar. Beirut. Lebanon:. Al- Maktab Al-Eslami.

[12] Arindo. (2013). Racism in Lincoln -Douglas debate in Ottawa. A thesis presented to the English Department, Faculty of Letters, Jember University.

[13] Baker \& Ellece. (2011). Key terms in discourse analysis. London, New York: : Continuum International Publishing Group.

[14] Baker, M. (1997). Thematic Roles and Syntactic Structure. In L. Haegeman (Ed.).

[15] Brown, G. and Yule, G. ( 1985). Discourse Analysis. Cambridge: . Cambridge University Press.

[16] Dijk, V. (1997). text and context: Exploration in the semantics and pragmatics of discourse. London:: Longman.

[17] EUMC. (2006). EUMC, (2006). Discrimination and Islamophobia. EU: European Monitoring Centre on Racism and Xenophobia.

[18] Fairclough and Wodak. (1997). Discourse and social change. Cambridge: Polity Press, 258.

[19] Fairclough, N. (1989). Language and Power. cambridge University Press :London: Longman.

[20] Fairclough, N. (1992). Discourse and social change. London: Polity Press.

[21] Fairclough, N. (1995b). Media Discourse. London: Edward Arnold.

[22] Gee, J. P. ( (1990)). Social linguistics and literacies: Ideology in discourses. London: The Falmer Press.

[23] Halliday, M. A. (1978). Language and Social Semiotics. London: Edward Arnold.

[24] Jefferson, T. (2018). BrainyQuote. Retrieved from BrainyQuote.com: https://www.brainyquote.com/quotes/thomas_jefferson_157212

[25] jubileeusa.org. (n.d.). The Last Sermon Of The Rasool PBUH. https://www.jubileeusa.org/.

[26] jubileeusa.org. (n.d.). www.jubileeusa.org. Retrieved from https://www.jubileeusa.org

[27] Le Bon, G. (1884). The Civilization of Arabs. Egypt:: Al-Halaby Press.

[28] Le Bon, G. (1884). The Civilization of Arabs. Egypt: Al-Halaby Press.

[29] Lucas, S. E. (1989). Justifying America: The declaration of independence as a rhetorical document, in Thomas W. Benson, ed., American rhetoric: Context and criticism. Lucas, S. E. (1989). Justifying America: The declaration of independence as a rhetoricaCarbondale, Illinois: Southern Illinois University Press.

[30] Nadawi, S. (. (2005). Nadawi, S. (2005). Islam and the world: Islam and the world: the rise and decline of Muslims and its effects of Mankind. United Kingdom: UK Islamic Academy.

[31] Omoloso, R. K. (2014). The Universality of the Last Sermon: A Universal Pragmatic Analysis. Al-Hikmah University, Ilorin, Nigeria.

[32] Omoloso. (2014). The Universality of the Last Sermon: A Universal Pragmatic Analysis. Al-Hikmah University, Ilorin, Nigeria.

[33] Orwell, G. (2016). Animal farm. Australia: eBooks@Adelaide.

[34] Reboul. (1797). Reductionism and contextualism in pragmatics and discourse analysis. Linguistische Berichte.

[35] Richards and Schmdit . (2010). Longman dictionary of language teaching and applied linguistics. Uk: Saffron House.

[36] Sampson. (1980). School of Linguistics: Competition and Evaluation. London: Longman.

[37] Van Dijk, T. (1998a). Critical discourse analysis. http://www.hum.uva.nl/teun/cda.htm. (1/25/2000).

[38] Wang, J. (2010). A Critical discourse analysis of Barack Obama's speeches. Journal of Language Teaching and Research, $254-261$.

[39] Wodak, F. a. (1997). Discourse and social change. Cambridge: Polity Press.

[40] Zohery. (2010). A Textual analysis of the last sermon of Prophet Mohammed. Howard University spring. 